\title{
Nitrogen and Chicken Manure Effect on Corn Growth and Yield in Double Row Cropping Patterns
}

\author{
Eko Suprijono $^{1}$, Masdar ${ }^{2}$, Neli Apriza ${ }^{3}$, Bambang Gonggo ${ }^{4}$, Nanik Setyowati ${ }^{5}$, Zainal Muktamar ${ }^{6}$ \\ 1,2,5 Department of Crop Production, Faculty of Agriculture, University of Bengkulu, Indonesia \\ ${ }^{3}$ Agroecotechnology Study Program, Faculty of Agriculture, University of Bengkulu, Indonesia \\ ${ }^{4,6}$ Department of Soil Science, Faculty of Agriculture, University of Bengkulu, Indonesia
}

\begin{abstract}
Corn (Zea mays L.) is a common food and feed product in the community since it is commonly used as rice substitution as food staple. Fertilizer application is required to attain crop high yields. Plants can receive nutrients from synthetic nitrogen fertilizers (NF) during their growth cycle. However, excessive use of NF might harm the environment. Organic chicken manure (CM), on the other hand, can minimize the harmful impact of NF. Chicken manure benefits to improve the soil's physical, chemical, and biological properties. To boost maize plant growth and productivity, might employ CM and NF. The objective of this study was to determine the effect of NF and CM on corn growth and yield. This research was conducted in Kembang Seri, Central Bengkulu, Indonesia from November 2019 to February 2020 using Randomized Complete Block Design (RCBD) with two factors and three replications. The first factor was NF doses $(100,125$, and $150 \%)$, and the second-factor consisted of CM doses $(0,10$, and 20 tons/ha). Data were analyzed using ANOVA F-5\%. On shoot dry weight of corn cultivated in a double row cropping pattern, there was an interaction between the dose of $\mathrm{N}$ and chicken manure. At 0 tons/ha, the optimum $\mathrm{N}$ fertilizer dose for chicken manure is $135.96 \%$, or $407.86 \mathrm{~kg}$ urea/ha. At a dose of 20 tons/ha, the optimum $\mathrm{N}$ fertilizer dose for chicken manure is $141.22 \%$, or 423.65 $\mathrm{kg}$ urea/ha. In a double row cropping pattern, different nitrogen fertilizer doses had no effect on corn growth and yield. The optimal dose of chicken manure was 16.65 tons/ha for plant height, 17.35 tons/ha for stem diameter, 18.89 tons/ha for leaf greenness, 17.35 tons/ha for cob length, 15.01 tons/ha for cob weight, 18.87 tons/ha for dry seed weight/plant, and 19.74 tons/ha for dry seed weight/plot.
\end{abstract}

KEYWORDS: Chicken Manure, Corn, Double Row Cropping, Zea Mays.

\section{INTRODUCTION}

Corn (Zea mays L.) cultivation with a double row cropping pattern yields more than single row cropping. Plant spacing for optimal number of populations can increase land productivity. Planting with a single row planting system has frequently been used in corn cultivation; however, a double row planting method starts getting attention since it may generate larger yields on a less land area [1]. Close planting distances cause corn plants to receive insufficient sunshine, whereas too far apart necessitate more acreage for the same population [2]. Corn planted in a double row planting technique absorbs more water, receives more sunlight, and absorbs more nutrients [1]. A double row cropping technique can enhance plant population per unit area while also increase land productivity. The purpose of spacing is to maximize plant productivity by optimizing population and decreasing competition between plants [3].

Planting media, plant varieties, fertilizers, and climate influence plant growth and development. Plants cannot grow well, and production is low when plant growth requirements are unsuitable. In order to get a crop high yield, it is essential to consider the plant's environmental circumstances carefully. Likewise, fertilization is one way of increasing soil nutrient content to enhance corn plant growth and yield. Fertilizer is classified into two types: organic fertilizer and synthetic fertilizer. Organic fertilizers from microorganism decomposed organic substances release nutrients for plants without harming the soil or water. Organic matter is composed of partially weathered plants and animals [4]. Organic matter can help the soil enhance its physical, chemical, and biological qualities, providing nutrients to plants. The application of 15 tons/ha of organic manure is also required to improve soil chemical qualities such as increasing soil pH and Cation Exchange Capacity (CEC), as well as biologically by providing energy for macro-and microorganism activity, leading to the improvement of soil structure [5], improves soil physical properties, such as increasing the percentage of soil pores and soil permeability [6]. Organic matter is also required to improve soil chemical qualities 


\section{International Journal of Current Science Research and Review}

ISSN: 2581-8341

Volume 04 Issue 11 November 2021

DOI: 10.47191/ijcsrr/V4-i11-04, Impact Factor: 5.825

IJCSRR@ 2021

www.ijcsrr.org

such as increasing soil pH and Cation Exchange Capacity (CEC) and biologically by supplying energy for macro-and microorganism activity, thereby promoting the soil aggregation [5].

Ultisols is soil with a low $\mathrm{pH}$, and base saturation at a depth of $180 \mathrm{~cm}$ from the soil surface is less than $35 \%$. Ultisols fertility is very low because the content of nutrients such as $\mathrm{N}, \mathrm{P}, \mathrm{K}, \mathrm{Mg}$, and $\mathrm{Zn}$ are available in small quantities. Another disadvantage of Ultisols is their susceptibility to erosion [7]. Ultisols can improve their soil structure through the application of organic fertilizers. Organic fertilizers can be used to improve the soil structure of Ultisols.

Organic chicken manure (CM) is organic fertilizer, containing high $\mathrm{P}$ content, and provide macro and microelements. Furthermore, CM improves soil structure, thereby increasing water holding capacity, soil microbiological activity, CEC, and soil structure [8]. Organic chicken manure 10 tons/ha had a positive effect on plant height, stem diameter, number of leaves, and leaf area index of maize at three weeks after planting (WAP), 5 WAP, and 7 WAP [8]. Meanwhile, synthetic fertilizers used continuously without being balanced with organic matter might harm soil structure. The application of manure and synthetic fertilizers did not show any interaction between the two on the total $\mathrm{N}$ content of the soil, the efficiency of $\mathrm{N}$ uptake, and the weight of dry milled grain [9].

Nitrogen $(\mathrm{N})$ is an essential nutrient required by corn plants for growth and development. Some soil orders, such as Ultisols, Entisols, and Inceptisols, contain low $\mathrm{N}$ and other nutrient levels but high acidity (pH 5.5) [1]. Application of proper amount of $\mathrm{N}$ fertilizer incease corn yield. Urea fertilizer at a rate of $250 \mathrm{~kg} / \mathrm{ha}$ can boost corn plant growth and yield [10]. However, plants do not absorb released nutrients from fertilizer applied to the soil. Cultivated crops absorbed between 55 and $60 \%$ of $\mathrm{N}$ fertilizers, roughly $20 \%$ of $\mathrm{P}$ fertilizers, and 50 to $70 \%$ of $\mathrm{K}$ fertilizers. The response of plants to applied fertilizer is determined by the type of fertilizer used and the soil fertility. As a result, even though the type of plant is the same, the fertilizer dose varies depending on the planting area [11]. Complete fertilizer application (NPK) gives higher yields than without applying one of the nutrients N, P, or $\mathrm{K}$. The balance of the combination of $\mathrm{N}, \mathrm{P}$, and $\mathrm{K}$ fertilizers affects the efficiency of nutrient use [12]. The study aimed to determine the best combination of NF and CM for the growth and yield of corn, the optimum dose of NF for growth and yield of corn in a double row cropping pattern, and the optimum dose of CM for growth and yield of corn in a double row cropping pattern.

\section{MATERIALS AND METHODS}

The research was conducted from November 2019 to February 2020 in Kembang Sri Village, Central Bengkulu, Indonesia. The design used was Randomized Complete Block Design (RCBD), consisting of two factors and three replications. The first factor was the dose of nitrogen fertilizer consisting of $\mathrm{N}_{1}=100 \%(300 \mathrm{~kg} / \mathrm{ha}) ; \mathrm{N}_{2}=125 \% ; \mathrm{N}_{3}=150 \%$, and the second factor was the dose of chicken manure i.e. $\mathrm{A}_{1}=0$ tons/ha, $\mathrm{A}_{2}=10$ tons/ha, and $\mathrm{A}_{3}=20$ tons/ha. The experimental plot size was $2.95 \mathrm{~m} \mathrm{x} 1.9 \mathrm{~m}(\mathrm{w} \times 1)$. The number of plants was 40 per experimental plot and six plants for each plot as samples. As a comparison, there are three plots with a single row cropping pattern.

\section{Analyses of Soils}

Soil $\mathrm{pH}$ was measured using $\mathrm{pH}$ meter at ratio 1:2.5 of soil and distilled water, soil total nitrogen using Kjeldahl Method , exchangeable $\mathrm{Al}$ using titration method after extertaion of $1 \mathrm{~N} \mathrm{KCl}$, organic- $\mathrm{C}$ using Walkly and Black Method, cation exchange capacity (CEC) using $1 \mathrm{~N}$ ammonium acetate extraction, and soil bulk density using ring sample method.

\section{Land Preparation}

Land preparation started with removal of weed using manual method. The soil was hoed at the depth of $20 \mathrm{~cm}$ from the surface and at the same time, dolomite was applied based on exchangeable Al method. The soil tillage was repated to completely loosen the soil.

\section{Planting}

Corn seeds were planted at a depth of $2-3 \mathrm{~cm}$ and a spacing of $95 \mathrm{~cm}$ (between rows) x $25 \mathrm{~cm}$ (in rows) in a double row cropping pattern. Carbofuran at the dose of $0.2 \mathrm{mg} /$ plant was applied at the same time as seed planting to suppress insects.

\section{Fertilizer Application}

Manure was applied just before planting according to each treatment. Urea fertilizer was applied gradually in a grid pattern between plant rows. One-third portion of urea fertilizer was applied seven days after planting (DAP), while another one-third portion was applied at 30 DAP, and the rest at 45 DAP (Syafruddin, 2016). 


\section{International Journal of Current Science Research and Review}

ISSN: 2581-8341

Volume 04 Issue 11 November 2021

DOI: 10.47191/ijcsrr/V4-i11-04, Impact Factor: 5.825

\section{Plant Maintenance}

Irrigation was carried out to maintain soil moisture. Weed control was carried out twice, which are two weeks after planting (WAP) and 5 WAP. Pest control was carried out chemically with an insecticide with the active ingredient Deltamethrin at a dose of $2 \mathrm{ml} / \mathrm{L}$. In addition, the disease control was carried out using a fungicide with the active ingredient Mankozeb at a recommended dose.

\section{Observed variables}

The variables observed were plant height $(\mathrm{cm})$, stem diameter $(\mathrm{mm})$, leaf greenness, number of leaves, shoot dry weight $(\mathrm{g})$, cob length $(\mathrm{cm})$, cob diameter $(\mathrm{mm})$, cob weight $(\mathrm{g})$, dry seed weight/plant $(\mathrm{g})$, dry seed weight/plot $(\mathrm{g}), 100$ seed weight $(\mathrm{g})$. As supporting data, rainfall, soil moisture, and light intensity were recorded. Soil moisture was measured with a hygrometer, while light intensity was measured by a lux meter. The data were analyzed using Analysis of Variance with the F test at a 5\% significance level. Significantly different variables in the F test were then examined further using orthogonal polynomials.

\section{RESULTS AND DISSCUSSION}

Table 1. ANOVA analysis of $\mathrm{N}$ fertilizer, Chicken Manure, and their interactions on corn growth and yield.

\begin{tabular}{llll}
\hline \multirow{2}{*}{ Variables } & F-calculated & & Interaction \\
\cline { 2 - 3 } & Nitrogen & Chicken manure & $1,30 \mathrm{~ns}$ \\
Plant height & $0,71 \mathrm{~ns}$ & $4,84^{*}$ & $0,87 \mathrm{~ns}$ \\
Leaves number & $0,72 \mathrm{~ns}$ & $36,45^{*}$ & $2,04 \mathrm{~ns}$ \\
Stem diameter & $0,06 \mathrm{~ns}$ & $75,10^{*}$ & $1,40 \mathrm{~ns}$ \\
Leaves greeness & $1,67 \mathrm{~ns}$ & $28,92^{*}$ & $4,52^{*}$ \\
Shoot dry weight & $3,35 \mathrm{~ns}$ & $65,08^{*}$ & $2,66 \mathrm{~ns}$ \\
Cob length & $0,5 \mathrm{~ns}$ & $26,34^{*}$ & $2,35 \mathrm{~ns}$ \\
Cob diameter & $0,01 \mathrm{~ns}$ & $12,11^{*}$ & $1,64 \mathrm{~ns}$ \\
Cob weght & $1,39 \mathrm{~ns}$ & $9,03^{*}$ & $1,87 \mathrm{~ns}$ \\
Seed dry weight/plant & $0,05 \mathrm{~ns}$ & $22,92^{*}$ & $1,85 \mathrm{~ns}$ \\
Seed dry weight/plot & $0,25 \mathrm{~ns}$ & $50,95^{*}$ & $1,96 \mathrm{~ns}$ \\
100 seed weight & $0,57 \mathrm{~ns}$ & $6,51^{*}$ & \\
\hline
\end{tabular}

Note: $(\mathrm{ns})$ no significant different $(\mathrm{P}>0.05) ;(*)$ significantly different $(\mathrm{P}<0.05)$

The application of $\mathrm{N}$ fertilizer had no significant effect on all variables observed in this study, while chicken manure had a significant effect on all observed variables. There is an interaction between the dose of $\mathrm{N}$ fertilizer and chicken manure on the shoot dry weight.

\section{Interaction of $\mathbf{N}$ fertilizer and chicken manure dosage on shoot dry weight.}

The relationship between the dose of nitrogen fertilizer (NF) and shoot dry weight was linearly positive at chicken manure (CM) rate of 10 tons/ha and formed a quadratic pattern at a CM rate of 0 tons/ha and 20 tons/ha. The equation for the $\mathrm{CM}$ dose curve 0 ton/ha $\mathrm{Y}(0)=-0.4019 \mathrm{x} 2+109.29 \mathrm{x}-6910.7$ indicates that the optimum dose of $\mathrm{N}$ fertilizer has been obtained to produce the maximum shoot dry weight. The optimum NF dose was $135.96 \%$, or $407.8 \mathrm{~kg} / \mathrm{ha}$. The 10 ton/ha CM dosage curve's equation is $\mathrm{Y}(10)=4.1933 \mathrm{x}-160.06$, and the coefficient of determination $\left(\mathrm{R}^{2}\right)$ is 0.98 . The dose curve equation for $\mathrm{CM} 20$ tons/ha is $\mathrm{Y}(20)=$ $-0.2089 \times 2+59,003 \mathrm{x}-3600.8$, showing that the optimal dose of $\mathrm{N}$ fertilizer is $141.22 \%$, or $423.65 \mathrm{~kg}$ urea/ha, generating a shoot dry weight of $565,49 \mathrm{~g}$. 


\section{International Journal of Current Science Research and Review}

ISSN: 2581-8341

Volume 04 Issue 11 November 2021

DOI: 10.47191/ijesrr/V4-i11-04, Impact Factor: 5.825

IJCSRR@ 2021

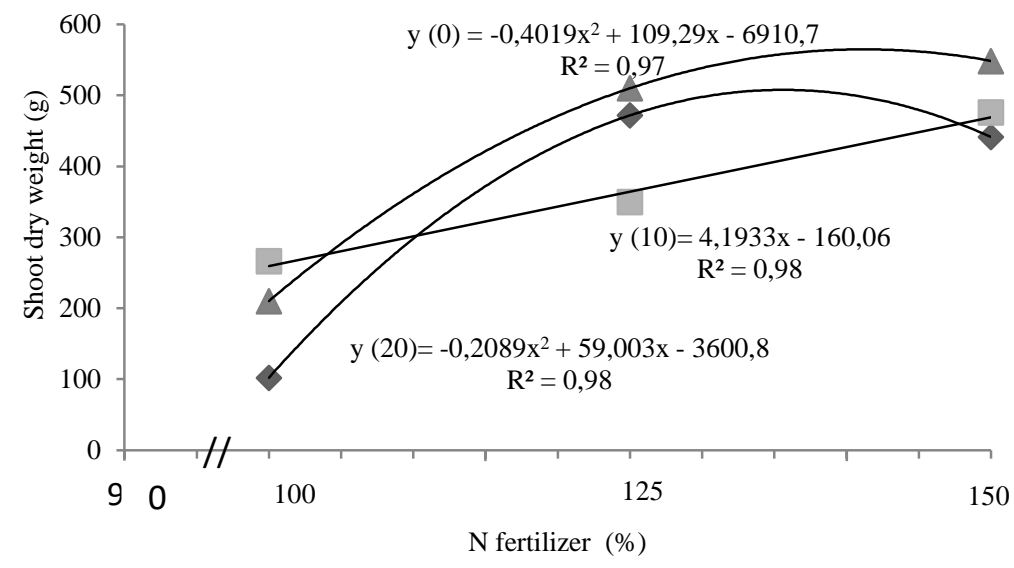

Figure 1. The interaction of dose of $\mathrm{N}$ fertilizer and chicken manure on shoot dry weight

A quadratic curve is not expected for a dose of CM 0 tons/ha (control treatment) because the theoretical hypothesis predicts that the application of NF will increase the shoot dry weight linearly. $\mathrm{N}$ treatment is intended to meet the nitrogen needs of corn plants in less fertile soils. Corn shoot dry weight in a CM treatment of 20 tons/ha with a double row cropping pattern was $565.49 \mathrm{~g}$, but only $168.38 \mathrm{~g}$ in a single row cropping pattern. The shoot dry weight is lower in the single row cropping pattern because the doses of NF and CM in the cropping pattern are lesser than in the double row cropping pattern. The higher the dose of $\mathrm{N}$ and $\mathrm{CM}$ fertilizer, the more nutrients are available to plants. The findings of another study by [13] confirmed that urea fertilizer had the most significant effect on plants since urea tended to enhance growth above the soil and produces green leaves, and in corn, it will enlarge the cobs and increase the protein content.

The combined application of NF and CM fertilizers provides sufficient and balanced nutrients for plant growth. Nutrients trigger the interaction between NF and CM in each fertilizer. The application of two fertilizers released nutrients $\mathrm{N}$ and $\mathrm{P}$, which were essential for cob development and seed filling processes. Since N and P are highly mobile nutrients in plant tissue, their deficiency will affect plant vegetative growth.

\section{Effect of $\mathrm{N}$ fertilizer on corn growth and yield}

Application of NF at different doses had no significant effect on plant height, leaves number, leaves greenness, and stem diameter (Table 2). The low soil $\mathrm{pH}$ at the study site affects the effectiveness of nutrient absorption by plant roots. $\mathrm{N}$ fertilizer is readily available and readily taken up by plants, whereas $\mathrm{CM}$ is a slow-release fertilizer. As a result, the availability of nutrients from $\mathrm{N}$ fertilizer and $\mathrm{CM}$ to plants does not occur concurrently.

Table 2. Average growth of corn at various doses of $\mathrm{N}$ fertilizer

\begin{tabular}{|c|c|c|c|c|c|}
\hline $\begin{array}{l}\mathrm{N} \text { dose } \\
(\%)\end{array}$ & $\begin{array}{l}\text { Plant height } \\
(\mathrm{cm})\end{array}$ & $\begin{array}{l}\text { Leaves } \\
\text { (helai) }\end{array}$ & number & $\begin{array}{l}\text { Leaves greeness } \\
(\mathrm{CCI})\end{array}$ & $\begin{array}{l}\text { Stem diameter } \\
(\mathrm{mm})\end{array}$ \\
\hline 100 & 169,41 & 7,87 & & 46,88 & 18,62 \\
\hline 125 & 174,37 & 8,72 & & 48,15 & 18,61 \\
\hline 150 & 174,61 & 8,81 & & 48,73 & 18,80 \\
\hline
\end{tabular}

Note: $\mathrm{CCI}=$ Chlorophyll Content Index

The application of NF at a rate of $150 \%$ tendend to have the highest plant height, leaves number, leaf greenness, and stem diameter (Table 2). This study's average plant height was lower than its potential, which reached $230 \mathrm{~cm}$. $\mathrm{N}$ element is a crucial nutrient for corn plant growth. $\mathrm{N}$ deficiency inhibits the process of cell division, resulting in slower plant growth. On the other hand, excess $\mathrm{N}$ will also affect corn plant growth by lengthening the vegetative growth cycle and causing it more vulnerable to fall. Thus, 


\section{International Journal of Current Science Research and Review}

ISSN: 2581-8341

Volume 04 Issue 11 November 2021

DOI: 10.47191/ijcsrr/V4-i11-04, Impact Factor: 5.825

IJCSRR@ 2021

www.ijcsrr.org

it is essential to ascertain the soil's nitrogen content to ensure that the supplied fertilizer is targeted correctly and appropriately utilized by the plants. $\mathrm{N}$ fertilizer has the advantage of being highly soluble in water and readily absorbed by plants. However, if $\mathrm{NF}$ is applied to the soil surface, the amount of $\mathrm{N}$ lost to the atmosphere can approach $40 \%$ of the amount used [14].

The application of NF at a rate of $150 \%$ tended to exhibit the highest plant height, leaves number, leaf greenness, and stem diameter. Lime application to the soil can help prevent nitrogen loss to the air. The liming process improves soil qualities, particularly the $\mathrm{pH}$ of acidic soils such as those identified in this research area. Increasing the $\mathrm{pH}$ of the soil can assist in providing the $\mathrm{N}$ element required by corn plants. At a normal $\mathrm{pH}$, elemental $\mathrm{N}$ may be absorbed optimally, increasing the growth and yield of corn plants. The uptake of nitrogen by plants in lime-treated soil is more significant than in un-lime soil. This phenomenon demonstrates that liming can enhance the soil's $\mathrm{pH}$ and ammonium ion levels, hence increasing $\mathrm{N}$ uptake.

Similar to vegetative growth, the study also showed that applying NF at different doses also had no significant effect on all yield variables. Application of NF at different doses resulted in no further impact on cob length, cob diameter, cob weight, seed weight/plant, seed weight/plot, and 100 seeds weight (Table 3).

Table 3. Average corn yield at various doses of $\mathrm{N}$ fertilizer

\begin{tabular}{lllllllll}
\hline $\begin{array}{l}\text { N dose } \\
(\%)\end{array}$ & $\begin{array}{l}\text { Cob length } \\
(\mathrm{cm})\end{array}$ & $\begin{array}{l}\text { Cob } \\
(\mathrm{mm})\end{array}$ & diameter & $\begin{array}{l}\text { Cob weight } \\
(\mathrm{g})\end{array}$ & $\begin{array}{l}\text { Seed dry } \\
\text { weight/ } \\
\text { plant }(\mathrm{g})\end{array}$ & $\begin{array}{l}\text { Seed } \\
\text { weight/plot } \\
(\mathrm{g})\end{array}$ & $\begin{array}{l}\text { dry } \\
\text { weight } \\
(\mathrm{g})\end{array}$ \\
\hline 100 & 16,56 & 36,98 & 160,52 & 131,37 & 5011,11 & 25,46 \\
125 & 16,03 & 33,62 & 154,66 & 113,04 & 5777,77 & 24,85 \\
150 & 14,96 & 37,04 & 148,93 & 104,56 & 5054,07 & 25,39 \\
\hline
\end{tabular}

These findings suggest that the application of NF was not utilized optimally by plants. Plants can't grow optimal during the vegetative and generative phases if nutrients are not sufficient [15]. Plant development and output are influenced by various factors, including fertilizer dosage, application method, and growing environment [16].

\section{Effect of chicken manure dose on the growth and yield of corn}

As seen in Figure 2, increasing the CM dose increased plant height. The plant height will increase by $0.86 \mathrm{~cm}$ as $\mathrm{CM}$ increases by 1 ton/ha. Figure 3 shows, the quadratic relationship indicates that the optimum dose of CM was obtained for the number of leaves. The optimum CM dose was 16.65 tons/ha, and the double row cropping pattern generated 9.63 leaves, similar to the 9.66 leaves produced by a single row cropping pattern.
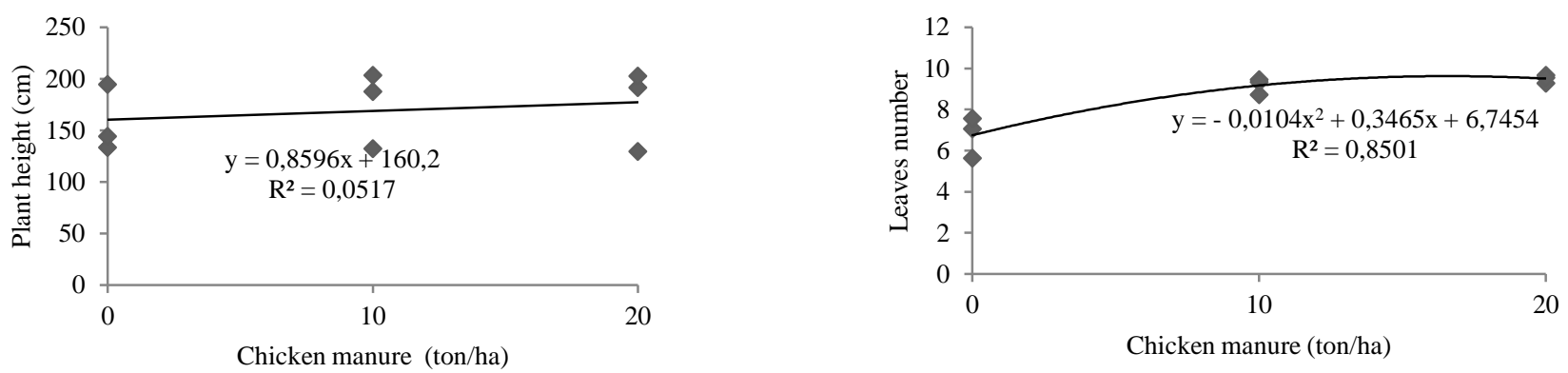

Figure 2. Relationship between dose of chicken manure and plant height Figure 3. Relationship between dose of chicken manure and leaves number

The application of $\mathrm{CM}$ had a significant effect on the greenness of the leaves (Table 1). The regression equation for the relationship between $\mathrm{CM}$ dose and leaf greenness is $\mathrm{Y}=-0.0211 \times 2+0.7974 \mathrm{x}+43.476$ (Figure 4). The quadratic relationship between CM application and leaf greenness revealed that the optimum CM dose was 18.89 tons/ha, resulting in leaf greenness in the double row cropping pattern of $51 \mathrm{CCI}$ and the single row planting pattern $53.46 \mathrm{CCI}$. Figure 5 shows, the regression equation 


\section{International Journal of Current Science Research and Review}

ISSN: 2581-8341

Volume 04 Issue 11 November 2021

DOI: 10.47191/ijesrr/V4-i11-04, Impact Factor: 5.825

for the relationship between $C M$ dose and stem diameter is $\mathrm{Y}=-0.0239 \mathrm{x} 2+0.8294 \mathrm{x}+14,367$, with $\mathrm{R}^{2}=0.9477$. As a result, the optimal dose of CM to achieve the maximum yield of stem diameter is 17.35 tons/ha $(21.56 \mathrm{~mm})$. Stem diameter planted in a single row cropping method had a greater diameter of $43.28 \mathrm{~mm}$.

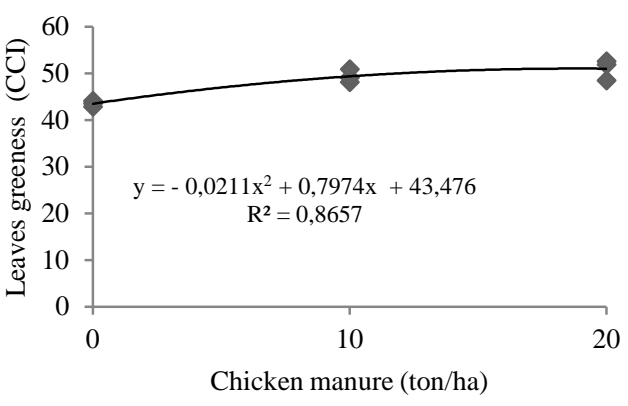

Figure 4. Relationship between dose of chicken manure and leaves greeness

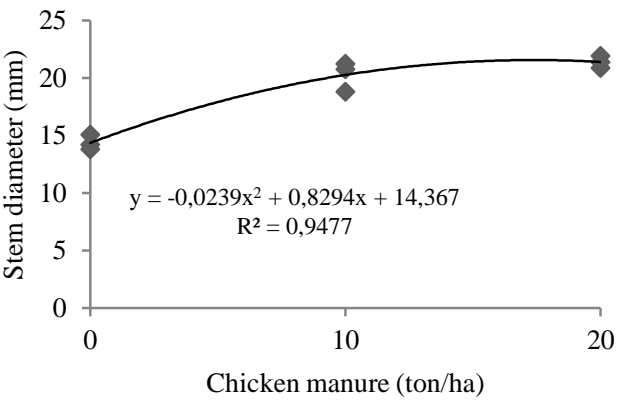

Figure 5. Relationship between dose of chicken manure and stem diameter

The CM application increased the length of the cob with the regression equation $\mathrm{Y}=0.1296 \mathrm{x}+14,558$ and the coefficient of determination $\left(\mathrm{R}^{2}\right)=0.3162$ (Figure 6). Each increase of 1 ton/Ha CM increases the length of the cob by $17.15 \mathrm{~cm}$. The application of CM resulted in a linear curve with the diameter of the cob, a regression equation of $\mathrm{Y}=0.4967 \mathrm{x}+30.919$, and a coefficient of determination $\left(\mathrm{R}^{2}\right)$ of 0.4291 (Figure 7). By increasing 1 ton/Ha CM, the diameter of the cob will increase by 0.4967 $\mathrm{mm}$.

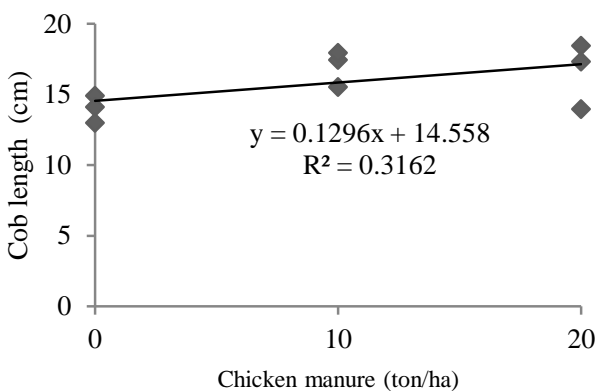

Figure 6. Relationship between dose of chicken manure and cob length

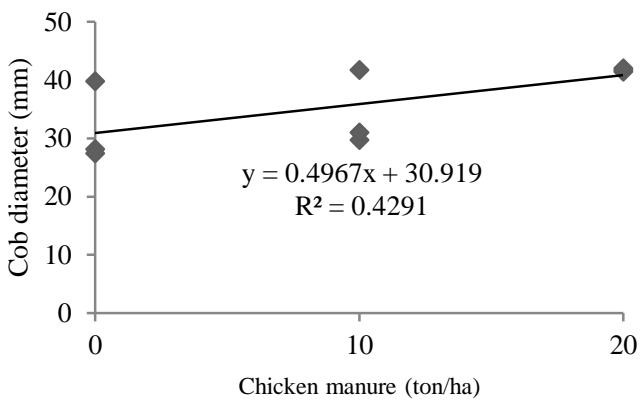

Figure 7. Relationship between dose of chicken manure and cob diameter

The regression equation between $\mathrm{CM}$ dose and cob weight is $\mathrm{Y}=-0.443 \mathrm{x} 2+13.307 \mathrm{x}+95.472$ with the coefficient of determination $\left(\mathrm{R}^{2}\right)=0.9243$, indicating a $92.43 \%$ relationship between the dose and cob weight (Figure 8). The quadratic relationship implies that the optimum CM dose has been attained to maximize cob body weight. The optimum CM dose was 15.01 tons/ha with a cob weight of $195.40 \mathrm{~g}$ in double row cropping. In comparison, the weight of cobs planted using a single row cropping design was somewhat greater, $215.72 \mathrm{~g}$. The use of $\mathrm{CM}$ has a considerable impact on seed dry weight/plant (Table 2). The regression equation $\mathrm{Y}=-0.1318 \mathrm{x} 2+4.9753 \mathrm{x}+88.531$ with a coefficient of determination $\left(\mathrm{R}^{2}\right)=0.595$ denotes a $59.5 \%$ association between CM dose and seed dry weight (Figure 9). 


\section{International Journal of Current Science Research and Review}

ISSN: 2581-8341

Volume 04 Issue 11 November 2021

DOI: 10.47191/ijesrr/V4-i11-04, Impact Factor: 5.825

IJCSRR@ 2021

www.ijjcsrr.org

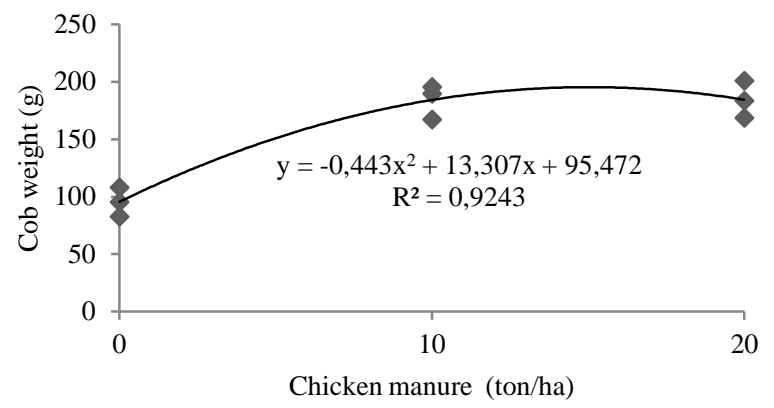

Figure 8. Relationship between dose of chicken manure and cob weight

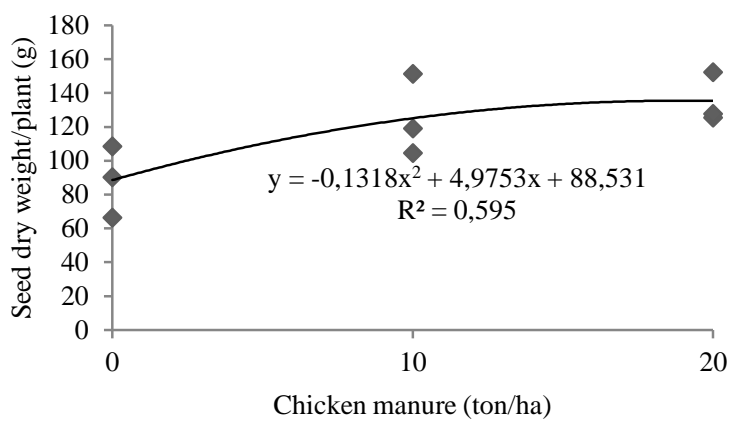

Figure 9. Relationship between dose of chicken manure and seed dry weight/plant

The relationship between CM dose and dry seed weight yielded an optimum value of 18.87 tons/ha with a dry seed weight of $135.48 \mathrm{~g} /$ plant in a double row cropping pattern and $177.34 \mathrm{~g}$ in a single row cropping scheme. The regression equation between the dose of $\mathrm{CM}$ and corn seed dry weight/plot is $\mathrm{Y}=-5.8074 \mathrm{x} 2+240.59 \mathrm{x}+4444.4$ with the coefficient of determination $\left(\mathrm{R}^{2}\right)=$ 0.9279, indicating a $92.79 \%$ association between the dose of CM and the dry weight (Figure 10).

The quadratic relationship suggests that the optimum dose of CM for increasing seed dry weight/plot has been found. Narrower spacing can boost productivity per unit area while lowering maize seed weight [17]. According to the findings of this study, the optimum dose of CM 20 tons/ha led to a seed dry weight of $6936.2 \mathrm{~g}$ in double row cropping pattern plots and $3822.2 \mathrm{~g}$ in single row planting pattern plots. With the regression equation, $\mathrm{Y}=0.3582 \mathrm{x}+21.654$ and the coefficient of determination $\left(\mathrm{R}^{2}\right)$ $=0.4792$, increasing the CM dose followed by increasing the weight of 100 seeds (Figure 11). Applying 1 ton/Ha of chicken manure increases the weight of 100 seeds by up to $0.3582 \mathrm{~g}$.

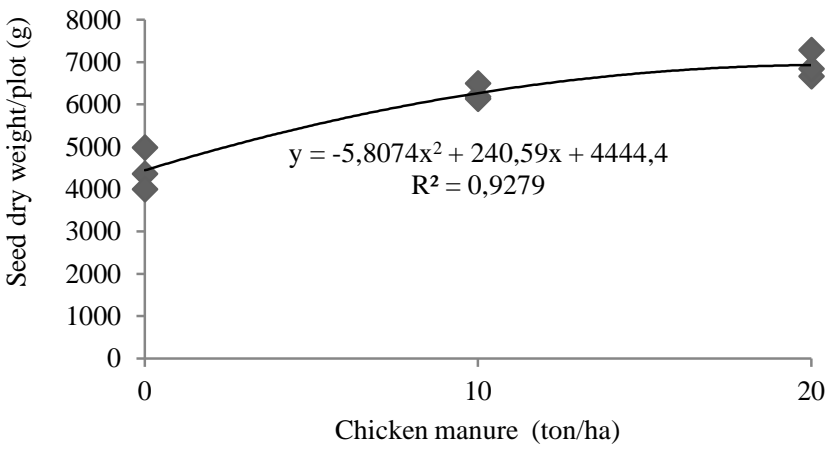

Figure 10. Relationship between dose of chicken manure and cob weight/plot

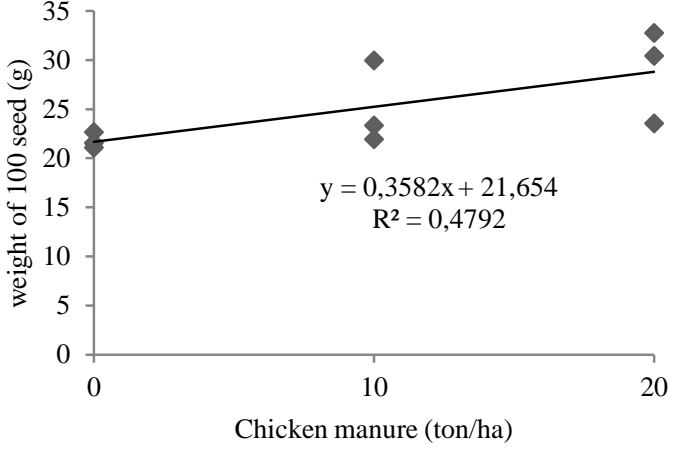

Figure 11. Relationship between dose of chicken manure and 100 seed weight

Overall, the results demonstrated that the higher the dose of CM, the better the corn growth and yield. Plant height, number of leaves, leaves greenness, stem diameter, cob length, cob diameter, cob weight, and seed dry weight increased as CM dose increased (Figure 2-11). Therefore, CM boosts soil fertility. Organic matter treatment can enhance and provide both macro and micronutrients to plants. According to Mayadewi (2007), CM provides nutrients N, P, and K that corn needs for vegetative growth, such as leaf growth. The higher the leaf chlorophyll content, the greater the photosynthesis process and the higher the yield of corn plants.

Corn grown in a single row cropping system had somewhat greener leaves than corn in a double row cropping arrangement. Photosynthesis in plants will run properly, and plant growth enhanced with the fulfillment of nutrients and radiation [18]. Elemental $\mathrm{N}$ is found in various substances, including amino acids, required for vegetative growth in plants, such as stems, leaves, and roots. When $\mathrm{N}$ is available for corn plants, all cell activities normally work [19]. According to [20], the better the stem's growth, the better 


\section{International Journal of Current Science Research and Review}

ISSN: 2581-8341

Volume 04 Issue 11 November 2021

DOI: 10.47191/ijesrr/V4-i11-04, Impact Factor: 5.825

IJCSRR@ 2021

WWw.ijesrr.org

the roots' ability to absorb nutrients, and the more nutrients received by the plant. Roots serve various functions, including nutrient absorption and nutrient transfer from roots to stems, leaves, and fruit [21]. [22] stated that the higher the photosynthetic process, the more food stores are transferred to seeds, assuming that other parameters like light, water, temperature, and nutrients are optimal. According to [23], the role of manure is to improve soil structure, supply a source of nutrients, increase the soil's ability to hold water and increase the soil's capacity to keep nutrients.

\section{CONCLUSIONS}

1. There was an interaction between the dose of $\mathrm{N}$ and chicken manure on shoot dry weight of corn cultivated in a double row cropping pattern. The optimum dose of $\mathrm{N}$ fertilizer for chicken manure at 0 tons/ha is $135.96 \%$, equivalent to $407.86 \mathrm{~kg}$ $\mathrm{urea} / \mathrm{ha}$. The optimum dose of $\mathrm{N}$ fertilizer for chicken manure at a dose of 20 tons/ha is $141.22 \%$, equivalent to $423.65 \mathrm{~kg}$ urea/ha.

2. Various doses of nitrogen fertilizer had no apparent effect on corn growth and yield in a double row cropping pattern.

3. The optimal dose of chicken manure was 16.65 tons/ha for plant height, 17.35 tons/ha for stem diameter, 18.89 tons/ha for leaf greenness, 17.35 tons/ha for cob length, 15.01 tons/ha for cob weight, 18.87 tons/ha for dry seed weight/plant, and 19.74 tons/ha for dry seed weight/plot. Application of 15-20 ton/ha of chicken manure will eventually increase growth and yield of corn.

\section{ACKNOWLEDGMENT}

Highly appreciation goes to Department of Crop Production, University of Bengkulu for providing financial support and necessary facilities of this project.

\section{REFERENCES}

1. Wahyudin, A., Yuwariah, Y., Wicaksono, F.Y., and Bajri, R.A.G. 2017. Maize response due to legowo planting system (2:1) and various doses of nitrogen fertilizers in inceptisol soil of Jatinangor. Jurnal Kultivasi, 16(3):507-513.

2. Desyanto, E., and Susetyo, H.B. 2014. The effect of plant spacing on the growth of greeney and yield of forage maize towards Bisi and Pioneer varieties in marginal land. Jurnal AgroUPY, 5(2):50-66.

3. Erawati, B.T.R., and Hipi, A. 2016. Pengaruh jarak terhadap pertumbuhan dan hasil beberapa varietas jagung hibrida di kawasan pengembangan jagung kabupaten sumbawa. Prosiding Seminar Nasional Inovasi Teknologi Pertanian. 20 July 2016, Banjarbaru. pp: 608-616.

4. Sutanto, R. 2002. Pertanian Organik Menuju Pertanian Alternatif dan Berkelanjutan. Kanisius, Yogyakarta.

5. Hairiah, K., Utami, S. R., Suprayoga, D.D., Widianto, Sitompul, S.M., Sunaryo, Lusiana, B. B., Mulia, R., Van Nordwijk, M., and Cadosch. 2000. Agroferestri pada tanah masam di daerah tropika basah: pengelolaan interaksi antara pohon tanaman semusim. Internasional Centre for Reserch in agroforestry (ICRAF). Bogor.

6. Nursyamsi, D.1999. Penggunaan bahan organik untuk untuk meningkatkan efisiensi pupuk N pada ultisol Sitiung Sumbar. Staf Peneliti Pusat Penelitian Tanah Agroklimat. Bogor. Thesis. Program Pasca Sarjana Universitas Gadjah Mada, Yogyakarta.

7. Notohadiprawiro, T. 2006. Ultisol, Fakta dan Implikasi Pertanian. Bulettin Pusat Penelitian Marihat, Sumatra Utara. Medan.

8. Ishak, S.Y., Bahua, M.I., and Limonu, M. 2013. Effect of manure fertilizer on the maize growth in Dulomo Utara of Gorontalo City. Jurnal Agroteknologi Tropika, 2(1):210-218.

9. Supramudho, G. N. 2008. Efisiensi serapan N serta hasil tanaman padi (Oryza sativa L.) pada berbagai imbangan pupuk kandang puyuh dan pupuk anorganik di lahan sawah palur Sukoharjo. Skripsi. Fakultas Pertanian, Universitas Sebelas Maret, Surakarta.

10. Pernitiani, N.P., Made, U., and Adrianton. 2018. The effect of various doses of nitrogen fertilizer onthe growthand yield of sweet corn (Zea mays saccharata). Jurnal Agrotekbis, 6(3):329-335.

11. Syafruddin, Faesal, and Akil, M. 2013. Pengelolaan hara pada tanaman jagung.

http://balitsereal.litbang.pertanian.go.id/wp-content/uploads/2016/11/satuempat.pdf. Download 20 May 2019. 


\section{International Journal of Current Science Research and Review}

ISSN: 2581-8341

Volume 04 Issue 11 November 2021

DOI: 10.47191/ijesrr/V4-i11-04, Impact Factor: 5.825

IJCSRR@ 2021

www.ijesrr.org

12. Syafruddin. 2016. Fertilizer recommendation of N, P and K site-spesific location for maize cropping in Gowa District, South Sulawesi. Jurnal Pengkajian dan Pengembangan Teknologi Pertanian, 19(2):119-133.

13. Buckman, H.O. dan Brady, N.C. 1982. Ilmu Tanah. (Terjemahan: Soegiman). BharataKarya Aksara, Jakarta.

14. Lingga, P dan Marsono. 2007. Petunjuk Penggunaan Pupuk. Penebar Swadaya. Jakarta.

15. Novizan. 2002. Petunjuk Pemupukan Efektif. Agromedia. Jakarta.

16. Pratiwi, S.T. 2008. Mikrobiologi Farmasi. Erlangga. Bandung.

17. Mayadewi, N. N. A. 2007. Effect of farm manure materials and plant spacing on weed growth and sweet corn yield. Jurmal Agritop, 26(4):153-159.

18. Hakim, N., Nyakpa, M.Y., Lubis, A.M., Nugroho, S.G., Diha, M.A., Hong, G.B. and Bailey, H.H. 1986. Dasar-Dasar Ilmu Tanah. Universitas Lampung.

19. Lakitan, B. 1996. Fisiologi Tumbuhan dan Perkembangan Tanaman. PT Raja Grafindo Persada. Jakarta.

20. Fahmi, A., Radjagukguk, B., and Purwanto, B.H. 2009. Phosphate and ferrous solubilty on acid sulphate soils treated with rice straw. Jurnal Tanah Tropika, 14(2):119-125.

21. Rosmarkam, A., and Yuwono, N.W. 2002. Ilmu Kesuburan Tanah. Kanisius. Yogyakarta

22. Dahlan and Arya, Z.P. 2008. Pengaruh Jarak Tanam Pagar Berganda terhadap Pertumbuhan dan Produksi Tanaman Jagung. Jurusan Penyuluhan Pertanian STPP Gowa. Gowa

23. Setiawan, B.S. 2014. Membuat Pupuk Kandang Secara Cepat. Penebar Swadaya. Jakarta.

Cite this Article: Eko Suprijono, Masdar, Neli Apriza, Bambang Gonggo, Nanik Setyowati, Zainal Muktamar (2021). Nitrogen and Chicken Manure Effect on Corn Growth and Yield in Double Row Cropping Patterns. International Journal of Current Science Research and Review, 4(11), 1495-1503 